\title{
Were ethical and legal issues violated, or was the book Mandela's Last Days censored?
}

\author{
Censorship ends in logical completeness when nobody is allowed to read any books except \\ the books nobody can read (George Bernard Shaw)
}

To the Editor: Nobel Peace Prize laureate Nelson Rolihlahla Mandela (Madiba) was the first black president of the Republic of South Africa $(\mathrm{SA})$, the iconic figure of the liberation struggle against apartheid and the unique moral voice of the world. ${ }^{[1]}$ Many books have been written about Madiba, including his own autobiography, Long Walk to Freedom, ${ }^{[2]}$ but none has drawn more controversy than the recently published book, Mandela's Last Days, authored by retired military doctor, Lieut. Gen. Vejay Ramlakan (VR). ${ }^{[3]}$ According to the publisher's author biography, VR has been a member of the African National Congress (ANC) for approximately 40 years, he was incarcerated on Robben Island from 1987 to 1991 and he was the surgeon general of the SA National Defence Force (SANDF) from 1995 to 2013. ${ }^{[3]}$ He was charged with the responsibility of providing healthcare to Madiba from 2005 until his death on Thursday 5 December 2013. ${ }^{[3]} \mathrm{His}$ rationale for penning the book was to 'recount one of the greatest triumphs of the human spirit and to set the record straight by rectifying the misconceptions, untruths, speculations and rumours about Mandela's last years. ${ }^{\prime[3]}$ Subsequently, VR has been accused of violating doctorpatient confidentiality by making Madiba's medical records and treatment public without consent, and for making intimate personal disclosures about the Mandela family, thus violating their dignity, trust and respect. ${ }^{[4]}$ In response, the publishers, Penguin Random House $\mathrm{SA}$, without contestation and at their own expense, withdrew the book from bookstores countrywide within less than a month of its publication (June 2017), and all further sales of the book have been censored 'out of respect for Madiba's family![4]

In his recent publication, McQuoid-Mason (MM) ${ }^{[6]}$ details the ethical and legal principles that ought to be followed with regard to who should consent to disclosing the medical records and treatment protocols of a deceased public figure, and whether such disclosures are in the public interest. It is a legal requirement that all healthcare workers (HCWs) must be registered with the Health Professions Council of SA (HPCSA), a statutory body, in order to practise their profession. Citing the HPCSA's ethical rules of conduct, MM states that 'confidential information about a deceased patient should only be divulged with the written consent of his or her next of kin or the executor of his or her estate, failing which such information ought to be disclosed in terms of a statute or court order or the disclosure if justified in the public interest..[6] Neither the HPCSA rule ${ }^{[6]}$ nor the dictionary ${ }^{[7]}$ provides a clear definition of next-of-kin. The latter defines next of kin as a 'person's closest living relative or relatives, next to 1 . bedside, 2 . following in order of importance.! ${ }^{[7]}$ Who should consent in instances where there are family disagreements? Under such circumstances, MM submits that one should be guided by the National Health Act (NHA) No. 61 of 2003, which describes the order of persons who can give written consent on behalf of incompetent live patients or deceased persons to make public personal medical information and treatment. ${ }^{[6]}$ The specific order of precedence is: 'a spouse or partner, a parent, a grandparent, an adult or a brother or sister of the person.'[6] By this definition, Madiba's widow, Graça Machel, has the legal authority to provide written consent, and not his ex-wife, Winnie Madikizela-Mandela, from whom Madiba was divorced (even though she was the only person at Madiba's bedside as he drew his last breath), ${ }^{[3]}$ nor the other categories of persons listed by the NHA. ${ }^{[6]}$

VR has repeatedly claimed that he was given permission to pen the book at the request of the 'family representative' who gave approval. ${ }^{[3]}$ The press recently reported that none among Graça Machel (Madiba's widow), Winnie Madikizela-Mandela (his ex-wife), Mandla Mandela (his grandson), the executors of his estate and the Nelson Mandela Foundation, or the SANDF gave their consent. ${ }^{[4]}$ To date the 'family representative' is known only to VR. ${ }^{[3]}$ Although the law makes no distinction between oral and written consent, it is easier to prove written consent in the case of a dispute..$^{[5]}$

VR repeatedly reaffirms in the book that paramount in his mind when treating Madiba were 'the requirements of doctor-patient confidentiality; state craft and state secrets; military protocol and the need for secrecy; addressing family anxieties; and ethical and legal considerations ${ }^{\prime[3]}$ Further, VR affirms that in consultation with a medicolegal expert, he was familiar with and adhered to the basic tenets of medical ethics applicable to healthcare (autonomy, beneficence, non-maleficence and justice). VR was also familiar with SA health legislation (presumably the NHA), which according to VR states that 'a patient can, when well and lucid, give the power of informed consent to another person. If there is no mandate for this, then a spouse or partner, parent, grandparent, adult child or sibling (in that order) may take on the responsibility. Failing this, a court could make a ruling! ${ }^{[3]}$

VR argues that because Madiba was an iconic public figure, he (Madiba) had always been open about his health. In any event, much of Madiba's medical information was already in the public domain in Long Walk to Freedom, ${ }^{[2]}$ Nelson Mandela: Conversations with Myself, ${ }^{[8]}$ Mandela: The Authorized Portrait ${ }^{[9]}$ and in various other biographies about his life which VR quotes from and references in the book. ${ }^{[3]}$ VR further contends that 'Mandela appeared to view his health almost dispassionately, regarding it as a matter of public record [interest]. ${ }^{[3]}$ Under such circumstances, it may be argued that doctor-patient confidentiality may not have been violated. However, VR chronologically documented Madiba's new and deteriorating medical conditions and treatments with military precision during his last days, after Madiba retired from public office. ${ }^{[3]}$ Because Madiba was no longer in public office, his privacy about his medical condition should have been respected, according to $\mathrm{MM}^{\left[{ }^{[6]}\right.}$ In addition, while the 'information may be true, it should not have been published, because it is not necessarily material in which the public had an interest'.[6] 
VR had a longstanding relationship with Madiba and his family during the course of the liberation struggle and the years of incarceration on Robben Island, and as Madiba's personal physician. Therefore, it is safe to assume that VR had the trust and confidence of Madiba and his family. This is borne out in the book by the military-like precision and tactics (sometimes covert) that VR and his 'Charlie Team' of HCWs employed to serve and protect Madiba and his family in the last days. Certainly no expenses (taxpayers' monies) were spared. By his own admission, VR states that he obtained consent and that he was familiar with and adhered to the ethical and legal principles that were applicable and binding on him in providing adequate healthcare to his patient. The identity of the consentee/s remains unknown. Perhaps if VR had appended the signed consent document (if one exists) to the book, some of the controversies may have been resolved.

Hundreds of controversial books, including unauthorised biographies, have been published under the iconic Penguin emblem. Several books on Madiba that contain his medical records and treatment are in the public domain. It is unlikely that each one of these books was authorised by the family. The accuracy of the book has not been questioned. However, according to MM, 'the next of kin may sue in their personal capacity if they can prove that disclosures in the book were an unlawful invasion of their privacy. ${ }^{\text {!6] }}$ It is difficult to reconcile why the author, who was well versed in the ethical and legal requirements for the doctor-patient relationship, would allegedly violate these tenets. Post-apartheid SA no longer has censorship laws in place. ${ }^{[10]}$ Perhaps a powerful and influential family was able to bring pressure to bear on the author and the publishers to withdraw the book from the marketplace. ${ }^{[1]]}$ By not allowing the book to be judged on its merit, removing the book is, in fact, tantamount to censorship. ${ }^{[1]}$

\section{A Sathar}

Honorary Research Fellow, School of Law, University of KwaZulu-Natal, Durban, South Africa

aslamsathar@ymail.com

S Afr J Bioethics Law 2017;10(2):42-43. DOI:10.7196/SAJBL.2017. v10i2.608

1. Sathar MA. Mandela was the last of the truly moral leaders. Letters to the Editor. Durban: Sunday Tribune, 22 December 2013.

2. Mandela NR. Long Walk to Freedom: The Autobiography of Nelson Mandela. Johannesburg: Macdonald Purnell (Pty) Ltd, 1994.

3. Ramlakan V. Mandela's Last Years. Johannesburg: Penguin Random House South Africa, June 2017. [publication withdrawn]

4. Drum Digital. Winnie Mandela breaks her silence on Mandela's book. 27 July 2017. http://www.drum.co.za/news/winnie-mandela-breaks-her-silence-on-mandelasbook/ (accessed 19 August 2017).

5. Dada MA, McQuoid-Mason DJ. Introduction to Medico-Legal Practice. Durban: LexisNexis, 2001(5-32).

6. McQuoid-Mason DJ. Disclosing details about the medical treatment of a deceased public figure in a book: Who should have consented to the disclosures in Mandela's Last Days? S Afr Med J (in press), 2017.

7. Soanes C, Hawker S (eds). Compact Oxford English Dictionary, 3rd Edition Oxford: Oxford University Press, 2005.

8. Mandela NR, Nelson Mandela Foundation. Nelson Mandela: Conversations with Myself. London: Macmillan Publishers Ltd, 2010.

9. Parkin K (ed.). Mandela: The Authorised Portrait. Johannesburg: Wild Dog Press, in association with PQ Blackwell, 2006

10. Merrett CP. Political censorship in South Africa: Aims and consequences. http:// www.sahistory.org.za/sites/default/files/DC/remar82.3/remar82.3.pdf (accessed 22 August 2017)

11. Le Roux L. The withdrawal of the Mandela book was nothing short of censorship. 15 August 2017. http://theconversation.com/the-withdrawal-of-the-mandelabook-was-nothing-short-of-censorship-82467 (accessed 18 August 2017).

Accepted 17 October 2017 